DOI: 10.7596/taksad.v2i2.235

\title{
An Inner Struggle: Under Western Eyes
}

\section{Hale YAĞLIDERE*}

\begin{abstract}
This study aims to shed light on the most significant aspect of the modern man's inner struggle in Joseph Conrad's Under Western Eyes. Joseph Conrad is one of the authors of the twentieth century who was influenced by the psychological philosophy and he makes use of this influence in his works deeply. He who synthesizes the inner nature of the modern man, having conflicts himself with the deeper analysis field of the psychology aims to point out the incomprehensible and unsettled inner nature of the modern man in Under Western Eyes.
\end{abstract}

Key Words: Alienation, psychology, unconscious, betrayal.

\footnotetext{
* Kafkas University, Turkey.
} 


\section{Introduction}

In this article, I would like to discuss alienation reality, inner chaos, lastly the pursuit of the redemption by examining in a modern literary work, Under Western Eyes of Joseph Conrad. Inner self is the most paramount issue that is adopted by the modern fiction writers. Additionally, the fear of loneliness, loss of identity, discontinuity of the social relations are all the basic themes which have been handled as the qualifications of the modern man. The man in the modern world is alone, indifferent, vain as well as he is in the hands of the haunting atmosphere of the century. This atmosphere can easily be felt within the psychology of the man. In this sense, the novel writers of the modern century hang their examinations upon the psychological treatment of the individual. Psychological engagement gives one an entry ticket to the world of the human unconscious; and the ticket makes one access to the film of the modern man in the universe, full with the phantoms. Thus, Joseph Conrad does exactly the same thing while scrutinizing the spiritual orientation of the man in Under Western Eyes with his protagonist, Razumov. He is the character in anguish and the one, who possesses the spiritual disintegration throughout the novel.

I would like to begin with a clear quotation from Under Western Eyes which I believe will shed light on the issue I intend to discuss first: "He was as lonely in the world as a man swimming in the sea. The word Razumov was the mere label of a solitary individuality. There were no Razumovs belonging to him anywhere." (Conrad, 2003, 6) The quotation, taken from the statements of the language teacher as narrator, says that Razumov is a solitary man and lives loneliness in this universe. He has no bondages to anyone. In this sense, he is only obsessed with his studying and the subject of the prize essay in order to feel belonging to somewhere. As a promising student, Razumov wants to regulate his life according to his intelligence. What is more, this silver medal as an essay prize represents his future and his aspirations how to be out of the revolutionary actions the world he lives. Not to be the part of these actions, Razumov tries to be wholly devoted himself to his studies. His future aims are the main essences of his existence as well as he is a man of order who is totally absorbed in his studies.

Unfortunately, Razumov's hopes are shattered with the arrival of a fellow student, Victor Haldin. Haldin is a figure in the novel who seeks for refuge after his assassination of a Minister of State, Mr. de P. That matter is the beginning of Razumov's tragedy which we read 
as the novel progresses. Additionally, why Haldin chooses Razumov to yield a shield for him is the basic question that arouses at this point. In this sense, Haldin clarifies the situation by saying:

-speaking to a superior mind like yours I can well say all the truth. It occurred to me that you-you have no one belonging to you- no ties, no one to suffer for it if this came out by some means. There have been enough ruined Russian homes as it is. But I don't see how my passage through your rooms can be ever known... (Conrad, 1980, 11)

Correspondingly, Haldin is inspired by the confidence in Razumov. As Haldin sees as an advantage to be under the confidential bases of Razumov, he wants Razumov to help him to vanish. After this demand, Razumov has a great dilemma in his innermost depths of his unconscious. He experiences a split psychology which after turns out to be a sickness or a breakdown. Razumov "saw himself shut up in a fortress, worried, badgered, perhaps ill-used. He saw himself deported by an administrative order, his life broken, ruined and robbed of all hope." (Conrad, 2003, 12) Clearly, Haldin robs of Razumov's hopes by choosing him. However, Razumov wants to come out of the situation in a quicker way and agrees on Haldin's wish to find Ziemianitch, the sleigh driver who is supposed to help Haldin to escape from the country. Razumov is also full of fear that brings forth moral dilemma in him. He is, now, captured by the dungeons of the spiritual burden that spreads anguish, conflict and misery into his essence of unconscious. And he is in the stage where "a feeling of horrible sickness came over him. 'I must be courageous,' he exhorted himself mentally. All his strength was suddenly gone as if taken out by hand." (Conrad, 2003, 15)

The struggle of Razumov between his reason and spiritual being has begun so suddenly that he is not capable whether it is reasonable or not to help this revolutionist. In this sense, in order to return to his ordinary and stable life, he becomes, in a way, the victim of his confidentiality that reflects to the outside.

On his way to find Ziemianitch to help Haldin, he is in the middle of the division towards his psychological breakdown. "I shall give him up" (Conrad, 1980, 38) and "---am I 
obliged to let that fanatical idiot drag me down with him?" (Conrad, 1980, 39) Conrad's exploration of Razumov's psychology brings a great enrichment to his art, and his use of psychology in his character delineation gives subtleties and depths to his portrayal of Razumov. Conrad makes the reader analyze Razumov's conflicts by his inner voices. The dilemma he has is triggered with the hallucinations he sees:

Suddenly on the snow, stretched on his back right across his path, he saw Haldin, solid, distinct, real, with his inverted hands over his eyes, clad in a brown close-fitting coat and long boots. He was lying out of the way a little, as though he had selected that place on purpose. The snow round him was untrodden. This hallucination had such a solidity of aspect that the first movement of Razumov was to reach for his pocket to assure himself that the key of his rooms were there. But he checked the impulse with a disdainful curve of his lips. He understood. His thought, concentrated intensely on the figure left lying on his bed, had culminated in this extraordinary illusion of the sight. Razumov tackled the phenomenon calmly. With a stern face, without a check, and gazing far beyond the vision, he walked on, experiencing nothing but a slight tightening of the chest. After passing he turned his head for a glance, and saw only the unbroken track of his footsteps over the place where the breast of the phantom had been lying. (Conrad, 1980, 38)

The hallucination pushes him into the darkness of his unconscious as well as into the dilemma between the reason and conscience. This situation supports the idea that he has great difficulty in balancing his mentality and spirituality. This duplicity brings Razumov into the clear point of informing Haldin to the police. That matter is the blossom of the betrayal act. Razumov informs Haldin to the police and gives him up since he constructs a blockade against Razumov's future and puts his future in danger. 
Berthaud points out: "Razumov's recoil from Haldin is not cowardice; it is not even moral abhorrence; it is chiefly a despairing resentment that the prospect of a sane, normal future is being taken away from him.” (Berthaud, 1978, 173)

Haldin's sudden presence makes Razumov's life hard and his end tragic. In a way, Haldin prepares Razumov's tragic end. Seeking to control his ontological being, he takes a decision to betray Haldin. Yet, this gets the worse results. His life is ruined and his future is not exactly the one he is supposed to build up. As Goonetilleke comments, "to the end of his life, he is literary and metaphorically haunted by Haldin, somewhat like Shakespeare's Macbeth, seeing Banquo's ghost." (Goonetilleke, 1990, 162) Razumov is haunted to the end of his life like the ghost of Banquo. Conrad draws a line between the inside and the apparent side of the man by focusing on the great dilemma Razumov holds on between the betrayal and faithfulness.

In a similar way, this betrayal act is like a curse that is supposed to last till the end of his life. The only possibility to get rid of this ill-mannered position is the basic question that arouses in the minds of the reader. Conrad employs the questioning nature of a man, seeking for salvation from the curse. C. B. Cox resembles Razumov's situation to the curse that the mariner has as:

Razumov's decision to betray him is like the Ancient Mariner's killing of the Albatross, an abandonment of the ties that bind man and nature, man and man. The claim Haldin made on him had fundamentally nothing to do with matters of politics and revolution. The betrayal is an archetypal sin, like the murder of a guest. Immediately, afterwards Razumov's character breaks to pieces under the burden of guilt. (Cox, 1977, 32)

The burden gets heavier than before. For Razumov, the life is unbearable, and it impossible to turn back to his early life. This agony in his soul is namely essential for him to arrive at an understanding of himself. After he is sent to Geneva by the authorities to be spy among the revolutionists there, his anguish becomes much deeper when he sees Victor Haldin's sister, Natalie Haldin. 
His mind is completely splits and the shattering floor of his deeds turns out to be profoundly bitter. In Tony Tanner's words, "Life for Razumov changes into a grotesque pantomime, a hideous farce, a monstrous puppet-show, a nightmare- anything but normal reassuring reality." (Goonetilleke, 1990, 166) The softness of Miss Haldin's heart makes the situation much unbearable for Razumov since the genuine love for Natalie causes him to fall apart and realizes that double life is intolerable.

The only way to get a salvation is through the confession. Razumov decides to confess both Miss Haldin and the activists who he really is. He makes his confession and figures out: "In giving Victor Haldin up, it was myself after all, whom I have betrayed most basely." (Conrad, 2003, 236) The humanity in the protagonist of the novel bursts into tears with the confessional deed. However, at the end of this confession, he doesn't get atonement. He "proceeds from crime to punishment to redemption, but Conrad do not reward Razumov for his courage. He lives on in Russia, crippled, deaf, getting weaker every day, a broken man.” Cox, 1977, 33) For Cox, Conrad draws his protagonist's end with a sorrowful life. As a matter of fact, Conrad displays a scene for the readers full with agony and semi-redemption.

We can clearly say that the humanizing effect on Razumov is with his love for Miss Haldin. Though he seeks for a moral refuge for himself throughout the novel, it is Natalie who leads him to confess in the end. Yet, his confession doesn't bring eternal happiness to him. Conradian character, Razumov is a tragic one that portraits a man who is imprisoned with the guilty of betrayal and seeks for redemption and a man who is trapped with the true love that leads him to the confession as atonement for his betrayal act. The conclusion of Under Western Eyes is the dramatic scene that the reader doesn't await to see for the tragic hero of the novel.

\section{Conclusion}

Conrad portrays the process of the moral discovery of Razumov throughout the novel. What is more, Razumov's confessions in the end all reveal a growing inner perception in sight of moral discovery. Conrad emphasizes moral vision in his creative writing art. Moral vision can be regarded as an expression of moral imagination. In Under Western Eyes, the color of moral discovery is in the same line with the fruitfulness of human existence. Hence, Conradian works presents us a novel system of morality. He clearly underlines the humanity over everything. 
Throughout the novel, we try to analyze Razumov's psychology before and after betrayal act. At the beginning, he is alienated and absorbed in his studies, afterwards; his guilty conscience begins to torment his mind. His betrayal ruins the meaning of existence. Consequently, Razumov's destiny comes to possess the implications of the absurd nature of the existence. All we concern about in the modern world is that this is puppet world which is devoid of human significance and this is a life without air since it has no a personal truth.

\section{References}

Berthoud, Jacques. (1978). Joseph Conrad: The Major Phase. Cambridge: Cambridge UP.

Conrad, Joseph. (1980). Under Western Eyes. London, Penguin Books.

Conrad, Joseph. (2003). Under Western Eyes. London, Dover Publications.

Cox, C.B. (1977). Conrad. London, Longman Group Limited.

Cox, C.B, ed. Conrad, Heart of Darkness, Nostromo and Under Western Eyes.

Goonetilleke, R.A. (1990). Joseph Conrad: Beyond Culture and Background. London, Macmillan.

Hampson, Robert. (1992). Joseph Conrad: betrayal and identity. Great Britain:The MacMillan Press.

Peters, John G. (2006). The Cambridge Introduction to Joseph Conrad. Cambridge, Cambridge UP.

Shakespeare, William. (2003). Macbeth in the Complete Works of William Shakespeare. London, Pordes. 